\title{
Three Pack
}

National Cancer Institute

\section{Source}

National Cancer Institute. Three Pack. NCI Thesaurus. Code C78775.

A product containing three individual units. 